\title{
IMPLEMENTASI ASEAN PLAN OF ACTION TO COMBAT TRANSNATIONAL CRIMES (STUDI KASUS HUMAN TRAFFICKING DI THAILAND PADA TAHUN 2006-2010)
}

\author{
Ani Khoirunnisa \\ Universitas 17 Agustus 1945 Jakarta \\ aniejubaidi@gmail.com
}

\begin{abstract}
The concept of human security is related to components that can not be replaced if the components are lost. Aside that the assessment of human security (especially for human trafficking cases) tends to be subjective so that parameters are difficult to determine universally. Citizens as an object must be protected by every states. But each states has their own interest on profits that will be obtained as foreign

exchange. Therefore, this paper will describe the problem of human trafficking in Thailand, which is difficult to deal with by states even though they have joint regulations. It cause by the difference of national interests. Although the community have the principle of non-intervention.
\end{abstract}

Keywords: human security, human trafficking, national interests.

\section{Pendahuluan}

Perdagangan manusia (human trafficking) adalah satu dari tiga kejahatan transnasional dengan keuntungan terbesar setelah perdagangan obat-obatan dan senjata illegal. ${ }^{1}$ Berdasarkan penelitian Patrick Belser, keuntungan dari kejahatan perdagangan manusia tidak hanya dinikmati oleh aktor-aktor yang terkait secara langsung, tetapi juga memberi nilai tambah dalam bentuk devisa bagi negara. Setiap tenaga kerja yang dieksploitasi secara ekonomi di Asia dan Pasifik memberikan nilai tambah US\$ 412 per orang. Sedangkan korban-korban yang dieksploitasi secara seksual memberi keuntungan sebesar US\$10.000. Fakta tersebut dapat menjadi salah satu penyebab maraknya perdagangan manusia hingga saat ini. Menurut laporan United Nations

\footnotetext{
${ }^{1}$ ECPAT, 2012. Stop Sex Trafficking on Children and Young People.[pdf], dalam http://ecpat.net/EI/Publications/Trafficking/Factsheet_Thailand.pdf (diakses pada 24 januari 2016)
} 
Global Initiative to Fight Human Trafficking tahun 2007, total 2,5 juta jiwa menjadi korban dari perdagangan manusia, $56 \%$ korban berasal dari wilayah Asia dan Pasifik. ${ }^{2}$

Di wilayah Asia khusunya Asia Tenggara, Negara Thailand adalah salah satu negara dengan kasus Human Trafficking terbanyak. . Sebagai negara yang sedang berkembang, sejak tahun 1990, peran Thailand memang tidak dapat dilepaskan dari bisnis perdagangan manusia. Thailand menjadi negara asal, negara transit, dan negara tujuan korban perdagangan manusia terbesar yang berasal dari berbagai negara. Thailand merupakan pusat eksploitasi seksual dan tenaga kerja di Sub wilayah Mekong Besar. Jadi perdagangan manusia yang terjadi juga melibatkan negara-negara yang berbatasan langsung dengan wilayah Thailand seperti Laos, Myanmar, dan Kamboja. Di saat yang bersamaan Thailand juga merupakan salah satu negara dengan arus migrasi terbesar terutama di Wilayah Sub Mekong. ${ }^{3}$ Sebagai negara transit perdagangan manusia, Thailand menjadi penadah korban hasil perdagangan yang berasal dari Rusia, Polandia, Ceko, dan Amerika Selatan. Umumnya Thailand juga mengirim korban perdagangan manusia ke negara lain seperti Jepang sebagai tujuan prioritas. ${ }^{4}$ Serta negara Belanda, Jerman, Australia via Malaysia, Hongkong, India, Malaysia, dan kawasan Timur Tengah dengan tujuan untuk bisnis seks luar negeri.

Selain dipekerjakan dalam prostitusi, korban perdagangan manusia yang terjadi di Thailand juga dipekerjakan sebagai buruh dengan bayaran rendah. Umumnya yang menjadi korban adalah penduduk dari negara yang berbatasan dengan Thailand. Bukan hanya sebagai negara asal, transit, dan sumber perdagangan manusia, tetapi Thailand juga menjadi negara asal, transit, dan sumber untuk migrasi internasional. Pada tahun 2008 pula, Pemerintah Thailand mengeluarkan The Alien Employment Act. Mengingat banyaknya arus migrasi yang masuk ke Thailand maka Pemerintah Thailand berusaha untuk meregulasi buruh migran dengan

\footnotetext{
${ }^{2}$ United Nation Global Initiative to Fight Trafficking (UN.GIFT), 2007. Human Trafficking: The Facts. [pdf]. [Online] dalam http://www.unglobalcompact.org/docs/issues_doc/labour/Forced_labour/HUMAN_TRAFFICKING__THE_FACTS_-_final.pdf

${ }^{3}$ ECPAT, Loc. Cit, 3.

${ }^{4}$ Wanchai Roujanavong, 2012. Human Trafficking: A Challenge to Thailand and the World Community.[pdf] Thailand, dalam 150th International Senior Seminar Visiting Experts' Papers.
} 
keterampilan rendah yang ingin bekerja di Thailand. Kebijakan ini berlaku untuk buruh migran yang berasal dari negara-negara tetangga Thailand seperti Myanmar, Kamboja, dan Laos.

Dari penjelasan singkat mengenai kasus Human Trafficking di negara Thailand diatas, maka rumusan masalah dalam tulisan ini adalah : Faktor apakah yang mendorong tingginya kasus Human Trafficking di Thailand? Dan bagaiman implementasi ASEAN Plan of Action to Combat Transnational Crimes dalam kasus Human Trafficking tersebut?

\section{Kerangka Konseptual}

Kepentingan nasional

Pendekatan Hans J. Morgenthau yang telah menjadi suatu paradigma dominan dalam studi politik internasional sesudah Perang Dunia II, yaitu Kepentingan Nasional (National Interest) merupakan pilar utama bagi teori tentang politik luar negeri dan politik internasional yang realis. Pemikiran Morgenthau didasarkan pada premis bahwa strategi diplomasi harus didasarkan pada kepentingan nasional, bukan pada alasan-alasan moral, legal dan ideologi yang dianggapnya utopis dan bahkan berbahaya. Menurutnya kepentingan nasional setiap negara adalah mengejar kekuasaan, yaitu apa saja yang bisa membentuk dan mempertahankan pengendalian suatu negara atas negara lain. Hubungan kekuasaan atau pengendalian ini bisa diciptakan melalui teknik-teknik paksaan maupun kerjasama. Sementara Kekuasaan (power) dan Kepentingan (interest) yang dianggapnya sebagai sarana sekaligus tujuan dari tindakan politik internasional. Para pengkritiknya, terutama ilmuan dari aliran saintifik, menuntut definisi operasional yang jelas mengenai konsep-konsep dasar itu. Namun Morgenthau tetap bertahan pada pendapatnya bahwa kedua konsep tersebut tidak boleh dikuantifikasikan. Menurut Morgenthau, "Kepentingan nasional adalah kemampuan minimum negara untuk melindungi, dan mempertahankan identitas fisik, politik, dan kultur dari gangguan negara lain. Dari tinjauan ini para pemimpin negara menurunkan kebijakan spesifik terhadap negara lain yang sifatnya kerjasama atau konflik,"5

Human Security

\footnotetext{
${ }^{5}$ Morgenthau, H. J. (1951). In Defense of the National Interest: A Critical Examination of American Foreign Policy. New York: University Press of America
} 
Dalam kajian tradisional, keamanan selalu ditafsirkan ke dalam konteks ancaman fisik (militer) yang berasa dari luar. Namun kecenderungan seperti itu berubah dalam wacana-wacana modern melalui dimensi keamanan kontemporer atau lebih dikenal dengan keamanan NonConventional Threat dengan melebarnya lingkup pemahamana mengenai keamanan. Dalam wacana modern, keamanan dalam konteks keselamatan penduduk (human security) dari berbagai bentuk ancaman menjadi sama pentingnya dibanding dengan keamanan negara. Konsep ini lahir setelah Perang Dingin berakhir, terkait dengan perubahan pola konflik di dunia, yaitu dengan tampilnya komflik internal sebagai fitur utama yang kemudia melahirkan konsep human security, yang menempatkan individu dan bukan hanya negara sebagai pusat perhatian masalah keamanan

\section{Pembahasan}

Konsep hubungan internasional tidak lagi berpola pada hubungan hanya antara negara dengan negara lain saja tetapi telah banyak aktor non negara yang mengambil peran penting dalam dunia internasional bersamaan dengan interdepedensi antara suatu negara dengan negara lain yang mengalami perubahan. Pada awalnya perdagangan barang dan jasa legal namun sekarang banyak terjadi perdagangan illegal yang melibatkan dua atau lebih negara dengan keuntungan yang di dapat jauh lebih besar dari perdagangan jasa dan barang yang dilakukan secara legal. Salah satu bisnis illegal yang sangat mengguntungkan adalah human trafficking atau perdagangan manusia.

Menurut data PBB bahwa kasus human trafficking justru banyak terjadi di negara-negara Asia-Pasifik. Thailand misalnya, salah satu negara di Asia Tenggara yang mengalami dampak besar dari maraknya kasus human trafficking. Bukan hanya sebagai negara asal, transit, dan sumber perdagangan manusia, tetapi Thailand juga menjadi negara asal, transit, dan sumber untuk migrasi internasional. Demi menjaga kepentingan negaranya, Pemerintah Thailand mengeluarkan The Alien Employment Act pada tahun 2008. Mengingat banyaknya arus migrasi yang masuk ke Thailand maka Pemerintah Thailand berusaha untuk meregulasi buruh migran dengan keterampilan rendah yang ingin bekerja di Thailand. Kebijakan ini berlaku untuk buruh migran yang berasal dari negara-negara tetangga Thailand seperti Myanmar, Kamboja, dan Laos. 
Tabel 1

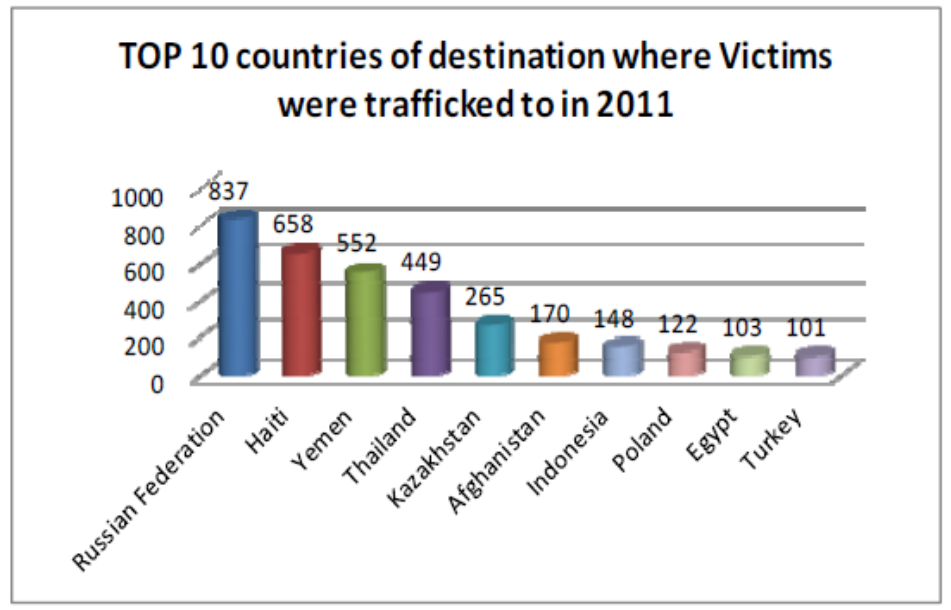

Tabel diatas menunjukkan Thailnad sebagai negara dengan tingkat Human Trafficking tertinggi. Pernyataan tersebut diperkuat dengan beberapa fakta yang ditemukan secara acak. Selama beberapa dekade terakhir, diperkirakan setiap tahunnya 25.000 korban berkewarganegaraan Thailand di Jepang yang mana 90\% adalah wanita menjadi korban yang harus menjadi pekerja seks komersial. Pada tahun 2006 juga ditemukan 280 yang dieksploitasi secara ekonomi dan diharuskan bekerja di bawah tekanan dan tidak digaji. Dalam jangka waktu 2006-2011 Thailand telah memulai usaha-usaha pemberantasan perdagangan manusia, tetapi sebaliknya tingkat arus perdagangan manusia yang terjadi juga semakin meningkat.

Terdapat beberapa faktor yang melatar belakangi tingginya Human Trafficking di negara Thailand : Pertama, Faktor kebudayaan, bahwa kebudayaan adalah cara untuk hidup dan cara untuk melakukan suatu hal, maka korban dari perdagangan manusia juga pasti memiliki cara hidupnya sendiri yang terikat oleh kepercayaan, tradisi, dan praktek kultural masing-masing. Dalam kebudayaan dalam perdagangan manusia, korban perdagangan manusia harus beradaptasi dengan kebudayaan baru jika ke negara asing. Tetapi ada pula budaya yang justru mendukung dan memungkinkan terjadinya perbudakan dan perkawinan paksa yang berujung pada perdagangan manusia. Kebudayaan ini sebenarnya tidak sesuai dengan hak asasi manusia, namun umumnya kebudayaan tersebut dihubungkan dengan ritual keagamaan dan keyakinan masyarakat setempat. Sedangkan kondisi internal dan konflik membentuk kondisi sosial dalam masyarakat. Pelaku perdagangan manusia akan dapat dengan mudah memperdaya para calon 
korban yang terjebak di tengah wilayah konflik dengan janji akan dibawa ke tempat yang lebih aman dan menyediakan lapangan pekerjaan. Rendahnya keterampilan kecakapan kerja juga memudahkan para pelaku untuk membujuk korbannya.

Kedua, Faktor ekonomi. Munculnya bisnis perdagangan manusia yang terus berjalan. Jahic mengatakan faktor ekonomi berperan secara timbal balik dengan informasi demografi di suatu wilayah yang berguna dalam proses rekrutmen. Terdapat beberapa faktor dalam perekonomian yang mempengaruhi muncul dan berjalannya bisnis perdagangan manusia. Faktorfaktor tersebut antaralain adalah kemiskinan dan pengangguran; migrasi sebagai strategi untuk bertahan hidup; dan analisis ekonomi terhadap tindak kejahatan.

Kemiskinan adalah penyebab terbesar terjadinya perdagangan manusia dalam sistem internasional. Pada banyak kasus, korban direkrut dari negara yang kurang berkembang dengan harapan mendapat kehidupan yang lebih baik di tengah ketidakpastian perekonomian dan tekanan politik. Krisis ekonomi global juga akan berimbas pada perekonomian negara berkembang yang memilih mengurangi tenaga kerja sehingga menghasilkan jumlah pengangguran yang masif. Himpitan situasi yang terjadi akibat kemiskinan akan menyebabkan masyarakat di wilayah tersebut bersedia melakukan pekerjaan apapun bahkan pergi dari wilayahnya. Kesediaan dari masyarakat tersebut menjadi keuntungan bagi para pelaku perdagangan manusia (trafficker).

Keinginan untuk mendapatkan kesempatan yang lebih baik dalam segi ekonomi, sosial, politik, dan ekonomi akan selalu mempengaruhi terjadinya migrasi. Tetapi strategi bertahan hidup melalui migrasi selalu berimplikasi akan kekagetan sosial secara eksternal maupun internal. Keluar masuknya arus migrasi di suatu negara, menjadi penawaran atas permintaan akan komoditas ilegal dalam perdagangan manusia. Kurangnya pengetahuan akan negara atau tempat tujuan menjadi kelemahan calon korban sehingga mudah diperdaya oleh pelaku perdagangan manusia yang menawarkan janji-janji materi dan penghidupan yang layak. Perdagangan manusia, eksploitasi tenaga kerja, dan arus migrasi adalah satu mata rantai yang selalu terhubung satu dengan yang lain. 


\section{Global Insight Journal}

Vol 03, No. 02

April- September 2018

ISSN 2541-318X

Gambar 1

Demografi Thailand

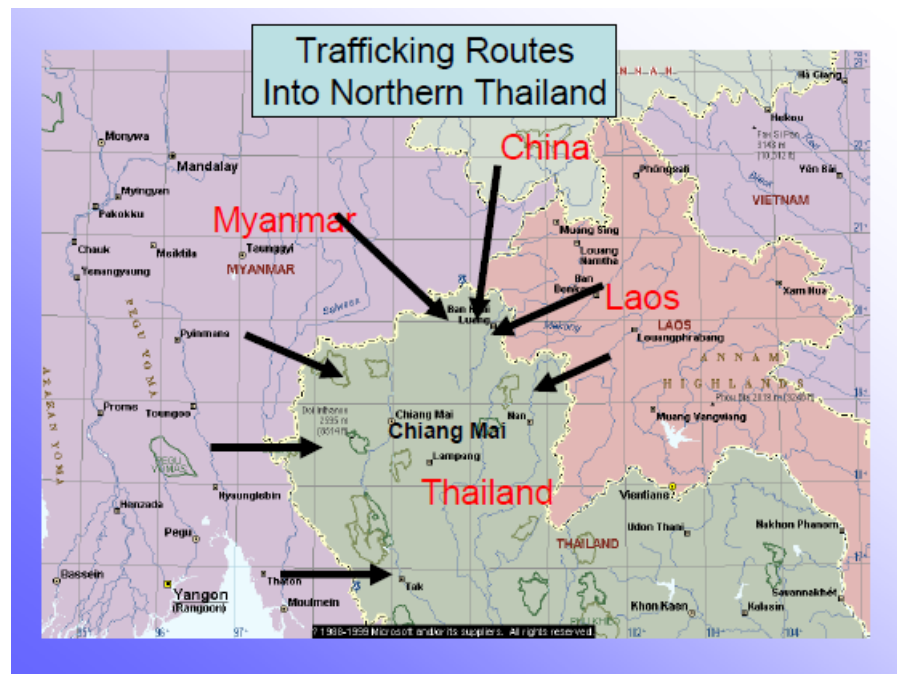

Sumber: Traffcord.

Secara demografis, wilayah utara Thailand memang didominasi oleh masyarakat beretnis minoritas yang kewarganegaraannya masih diragukan bahkan tidak mendapatkan simpati dari pemerintah. ${ }^{6}$ Seperti perdagangan pada umumnya, perdagangan manusia juga didasarkan pada hukum penawaran dan permintaan pasar. Hanya saja pergerakan mekanisme pasarnya sulit untuk diketahui karena merupakan bagian dari kegiatan ekonomi gelap (black economy) yang dilarang oleh hukum. Komoditas manusia memberikan berbagai keuntungan dalam bisnis perdagangan. Keuntungan-keuntungan tersebut antaralain adalah karena manusia tidak mudah binasa atau memiliki kemampuan untuk bertahan hidup; dapat diangkut jarak jauh; dan dapat digunakan kembali atau dijual kembali.

\footnotetext{
${ }^{6}$ Minority Rights Group International. 2013. Thailand: Highland Ethnic Groups [Online] dalam http://www.minorityrights.org/?lid=5608 (di akses pada tanggal 26 januari 2016)
} 


\section{Gambar 2}

Rute perdagangan manusia di Thailand

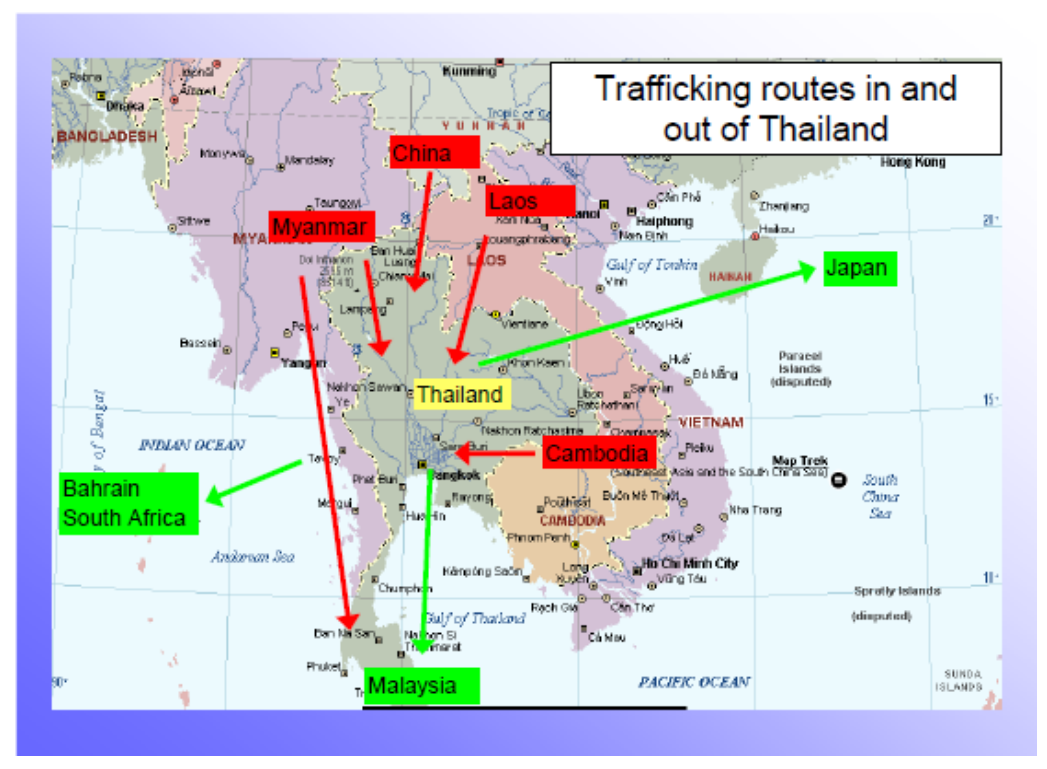

Sumber : Traffcord,

(http://www.iom.int/jahia/webdav/shared/shared/mainsite/microsites/IDM/workshops/managing _ return_migration_042108/presentations_speeches/iom_geneva_trafcord.pdf

Kondisi tersebut menjadi akar terancamnya keamanan bagi individu di negara Thailand.

Seperti bisnis legal pada umumnya, aktivitas kriminal akan cenderung berkembang di wilayah pusat perdagangan itu sendiri serta dekat dengan sumber komoditas. Dengan tingginya kasus human trafficking yang terjadi di negara Thailand ikut membawa negara negara yang memiliki integritas dan berada di satu kawasan dengan Thailand untuk membantu mencegah dan meminimalisir tingkat kejahatan transnasional tersebut.

ASEAN Plan of Action to Combat Transnasional Crimes adalah sebuah piagam atau regulasi yang dibuat oleh negara negara anggota ASEAN untuk menangani dan menjawab persoalan yang berhubungan dengan masalah keamanan dan kejahatan lintas batas negara yang terjadi di negara negara ASEAN. Yang dapat menggangu kedaulatan dan hubungan suatu negara dengan negara lain. ASEAN Plan of Action to Combat Transnasional Crimes didirikan pada 23 juni 1999 di Kuala Lumpur Malaysia dan disetujui oleh semua negara anggota ASEAN karena berpedoman pada masalah State Security yang berubah menjadi lebih kompleks yaitu human security yang berimplikasi pada keamanan non tradisional. Namun menurut analisa penulis 
dalam kasus human trafficking di negara Thailand tidak terlihat sebuah kesatuan dan dukungan dari negara-negara ASEAN sebagai suatu organisasi regional untuk mendukung pemerintah menangani kasus perdagangan manusia tersebut.

Semua negara anggota ASEAN hanya mengecam dengan tingginya korban dalam kasus tersebut namun tidak semua negara memberikan sumbangan pemikiran dan ikut membantu pemerintah Thailand khususnya dalam menangani kasus Human Trafficking ini. Hal tersebut berkenaan dengan prinsip No Intervention sebagai landasannya. Negara yang terlibat langsung dalam penanganan kasus ini adalah negara anggota ASEAN yang secara langsung maupun tidak langsung merasakan dampaknya. Thailand mengadakan kerjasama dalam bentuk Memorandum of Understanding (MoU) dengan Laos, Myanmar, dan Kamboja, dengan tujuan untuk mengontrol arus migrasi yang terjadi dengan meningkatkan kelayakan prosedur migrasi untuk pekerja migran, pemulangan pekerja migran yang lebih efektif, proteksi untuk pekerja migran, dan pencegahan penyusupan batas ilegal, perdagangan pekerja ilegal, dan pekerjaan ilegal pekerja. $^{7}$

Hal ini disinyalir bahwa keterlibatan pemerintah dalam kasus human trafficking namun tidak Nampak, dan juga karena beberapa negara di asia tenggara juga melakukan bisnis illegal yang sama namun tidak Nampak dan tidak di sentuh oleh dunia internasional sehingga seolah ingin menutup mata.

\section{Kesimpulan}

Perdagangan manusia (human trafficking) adalah satu dari tiga kejahatan transnasional dengan keuntungan terbesar setelah perdagangan obat-obatan dan senjata illegal. Salah satu negara yang menjadi negara yang terkena dampak dari maraknya human trafficking adalah negara Thailand. Negara Thailand tidak hanya menjadi mengada, namun juga sebagai tujuan dari destinasi perdagangan manusia dari berbagai negara. Dengan berbagai faktor yaitu faktor ekonomi dan kebudayaan.

Dengan tingginya kasus human trafficking di negara Thailand, sebagai negara yang tergabung dalam integritas negara-negara di Asia Tenggara, Thailand seharusnya dapat

\footnotetext{
${ }^{7}$ Cameron, Op. Cit, 146.
} 
menggunakan ASEAN Plan of Action to Combat Transnasional Crimes dalam kasus human trafficking untuk membantu penyelesaian dalam kasus tersebut dengan bantuan negara-negara ASEAN, namun bantuan dari negara-negara ASEAN lainnya tidak nampak karena adanya hukum No Intervention di ASEAN. Hal ini juga di sinyalir karena adanya keterlibatan pihak pemerintah yang membantu kejahatan lintas batas negara tersebut. Ini tidak terlepas dari kepentingan dari negara-negara masing-masing.

\section{Referensi ;}

Minority Rights Group International. 2013. Thailand: Highland Ethnic Groups

Morgenthau, H. J. (1951). In Defense of the National Interest: A Critical Examination of American Foreign Policy. New York: University Press of America.

Wanchai Roujanavong, 2012. Human Trafficking: A Challenge to Thailand and the World Community.[pdf] Thailand, dalam 150th International Senior Seminar Visiting Experts' Papers

Referensi lainnya;

http://ec.europa.eu/anti-

trafficking/download.action;jsessionid=0LTNRM4HncSHTLymJGTg1N30hLt9LY5tL9SKKjFrTsf WLQp6bPck!1062222535?nodePath=\%2FPublications\%2FIOM+Global+Trafficking+Data+on+A ssisted+Cases+2012.pdf\&fileName=IOM+Global+Trafficking+Data+on+Assisted+Cases+2012.pd $\mathrm{f}$

http://ecpat.net/EI/Publications/Trafficking/Factsheet_Thailand.pdf

http://www.iom.int/jahia/webdav/shared/shared/mainsite/microsites/IDM/workshops/managing_return_m igration_042108/presentations_speeches/iom_geneva_trafcord.pdf 